laboratory examination. Chemical analyses of the various coloured zones generally confirmed the results of previous investigators. Sulphur trioxide and phosphorus pentoxide have not generally been determined in earlier studies, and this work has thrown some light on their occurrence in open-hearth roof bricks. Nearer the hot face, $\mathrm{SO}_{3}$ was less than 0.2 per cent, but increased suddenly to nearly 0.6 per cent in the reddish cool end of the brick. The concentration of sulphur in this area is believed to have come from the furnace atmosphere, possibly during the making of certain free-cutting steels involving the addition of pyrites to the bath.

Phosphorus pentoxide remained fairly constant throughout the hotter half of the brick and then fell to a mere trace. Nowhere did the $\mathrm{P}_{2} \mathrm{O}_{5}$. CaO ratio approach that in the slag, nor were the positions of the two maxima coincident. This observation supports the view that the slagging agents in the furnace atmosphere contain but little furnace slag. Small amounts of lead, tin and copper were found in the roof brick, but the volatile zinc oxide was quite absent though abundant in the furnace flues.

Stalactites which formed on the underside of the roof, during the campaign, were found to resemble the hot face of the brick in composition, but the $\mathrm{FeO} . \mathrm{Fe}_{2} \mathrm{O}_{3}$ ratio nearly corresponded with that prevailing in the cooler portions of the black tridymite zone behind. This region of the brick was found to be less refractory than any other.

There was a general decrease of porosity towards the hot end of the roof bricks, which is in accord with the findings of previous investigators. Calculation, however, showed that the weight of absorbed fluxes is insufficient to account for the observed fall in porosity, and it must be assumed that some of the fluid glaze formed on the hot face is itself drawn up into the pores of the brick.

The region between the black tridymite and yellow zones, found in used roof bricks, has been shown to be of very low permeability. Microscopical work has confirmed this observation and indicated the presence of a narrow glassy continuum between the silica grains.

Microscopical examination of thin sections cut from the various zones has confirmed the observations of other workers on the stability of the various silica allotropes. The particular allotropes and their relative abundance in any given area have also been studied by coefficient of expansion curves and X-ray diffraction methods.

The formation of a eutectic between mellorite (a complex lime-ferric oxide-silicate of garnet type) and silica (tridymite or cristobalite) melting at about $1,160^{\circ} \mathrm{C}$. was observed and is a factor of importance in determining the life of roof bricks.

It has also been shown that furnace gases can pass through the brick, and sulphur compounds in the gases attack the glassy matrix forming ferric sulphate or ferric oxide, depending on the prevailing temperature.

1"Second Report on Refractory Materials." Iron and Steel Inst., Spec. Rep. No. 28, pp. 13-99 (1942).

a "Second Report on Refractory Materials." Iron and Steel Inst., Spec. Rep. No. 28, 101 (1942).

${ }^{8}$ Swinden, T., and Chesters, J. H., "Dolomite Bricks for use in Steelworks,"'J. Iron and Steel Inst., No. 2, $105 P$ (1941).

-Trans. Ceramic Soc., 33, 104 (1934).

"A Co-operative Investigation of the Factors Influencing the Durability of the Roofs of Basic Open-Hearth Furnaces". Report by the Open-hearth Refractories Joint Panel, J. Iron and Steel Inst., No. 2, 203P (1941)

\section{CAMBRIDGE SCIENTIFIC WORKERS AND THE WAR}

$A^{1}$

LTHOUGH recent surveys of the utilization of science in the War have tended to concentrate upon the situation in industry and in Government service, it must be remembered that the universities are carrying on a considerable volume of war research in addition to their main function of teaching. A critical review of the actual and potential war function of university research laboratories in Great Britain woukd provide a useful addition to present information, and their position must certainly be considered in any national scheme for the co-ordination of research. It is opportune, therefore, that on July 20 the Cambridge University Branch of the Association of Scientific Workers convened a meeting to discuss these points as they affect Cambridge. There was an attendance of more than a hundred, and contributions were forthcoming from research workers in most of the principal departments of the University.

A number of speakers reported on the general experience of their laboratories, other members of which supplemented their remarks in the discussions. The situation obviously varies considerably from department to department, but it is clear that some important difficulties are common to all. The main shortcomings may be summarized as: (1) lack of really important or urgent war problems in some laboratories, and the difficulty of obtaining such problems ; (2) continuance of academic research or, more frequently, occupation with 'pseudo' war research; (3) difficulty of effecting contact with workers in the same field in Government institutions or in industry; (4) hampering effect of secrecy regulations, which appear to be sometimes absurdly stringent; (5) lack of organized collaboration, including pooling of equipment, between the University departments; (6) difficulty under the present University regulations of employing $\mathrm{Ph} . \mathrm{D}$. research students on war work, particularly secret work and work carried on by research teams ; (7) absence of pooling of scientific teaching with the evacuated universities and colleges in Cambridge (the Cavendish Laboratory is a notable exception).

As was pointed out by the chairman, there are many scientific workers in Cambridge engaged on secret work of national importance, and their work could not be discussed at such a meeting. Hence the discussion possibly tended to place emphasis on the less satisfactory aspects of the situation. It is precisely these which most urgently need attention, however, and the volume of work represented was considerable.

The first two points are conveniently considered tngether. In the field of organic chemistry, for example, many of the post-graduate research students are working on problems recommended by the Advisory Research Council of the Chemical Society. It was stated that the majority of these problems are long-term problems related to the improvement of the post-war prospects of the chemical industry ; there is considerable dissatisfaction about this. Many senior members having left to do war-work, a considerable amount of teaching is carried on by the junior members of the laboratory, and it is undesirable to transfer all of them to posts elsewhere. The solution lies more in their being provided with the right sort of problems to solve. The situation is 
markedly better on the physical or colloid chemical side, where work is being done arising largely out of Service requirements, although some of it is rather long-term in nature. In 'pure' biochemistry it might be argued that there are very few real war problems at all, and this has led to quite a few research workers either continuing with academic research or taking up what might aptly be called a 'pseudo' war problem. It is necessary for biochemists to branch out into the related and more immediately useful fields of nutrition, medicine, bacteriology, agriculture and industrial fermentation. Difficulties here are the sketchy organization of biochemists for war purposes and the generally unco-operative attitude of industry.

The difficulty of meeting or corresponding with colleagues engaged on the same or similar work was instanced by speakers from various laboratories. The official attitude is often one of discouragement or even surprise, and many workers seem to have to rely on chance personal contacts. The stringency of secrecy regulations is sometimes too great, and has the undesirable effect of hampering the progress of work by preventing discussion with other scientific workers attacking similar problems. It is often particularly difficult for university men to obtain the necessary collaboration with industry or with Government laboratories.

The position of Ph.D. students was touched on by several contributors to the discussion. It is necessary to decide whether such persons are students being trained in some specialized branch of science, or whether they should be regarded as scientific workers of adequate experience to carry out successfully certain specific pieces of war work. The general opinion favoured the latter course as being more in line with the urgent needs of the situation, but it was felt that a modification of the University regula. tions to meet this point is necessary. Provision for students to submit secret war work in a dissertation for a higher degree has been made with apparent success in other universities, notably Oxford. Apart from secrecy precautions, there are difficulties in assessing a student's work if he has been working in a research team or has been engaged on a number of small isolated problems.

The crux of the matter was brought out by one speaker who gave a definition of war research. Scientific work can only be considered as war work when it is very probable that it will give results which can be applied to this War. Any other form of research is either 'pseudo' war work, or not war work at all. In particular, the urgent need for technical advance in the present eritical war situation must be realized. Probably the prime need is for individuals to appreciate their responsibilities to the nation, and themselves actively set about obtaining definite war problems. Difficulties, often considerable, do exist, but they must be expected and overcome. Many university scientific workers need to change their outlook and stop looking for a major research project in short-term pieces of work. Much of the difficulty arises because academic scientific workers are tempted too much to pick and choose their subjects for research. The essential thing now is the usefulness of the research, not its inherent scientific interest. They should be prepared to change over to completely new fields if there is little of direct application in their own, or even to take up work of a more routine nature. A man called up into the Forces has to learn a completely new art, so why not the man of science, who after all is in a sheltered position in the War?

While the meeting emphasized the need for personal initiative and hard work on the part of the individual man of science, it was clearly in no doubt that the setting up of a national body with executive power to plan scientific work is long overdue. A resolution, which was unanimously carried, gave expression to this opinion by supporting whole. heartedly the demands for a Joint Technical Board or Technical Planning Committee "with executive authority to co-ordinate research, design and development", and pointed out the necessity for such a body having the closest contacts with rank-and-file scientific workers. The maximum effort of Cambridge men of science to help the war effort was promised, and it was urged that, subject to necessary conditions of secrecy, all scientific workers engaged on similar problems or employed in the same place shall meet regularly to discuss progress and plan future advance.

\section{COBALT-NICKEL DEPOSITION}

A $\mathrm{N}$ article in the Electrical Review of July 3 by A c. C. Downio describes the developments which have taken place in the last three years on research into the deposition of cobalt-nickel alloy. This alloy is at least three times as hard as nickel itself, and is more resistant to corrosion than either cobalt or nickel alone. Moreover, the process is within the bright plating eategory which obviates the need for subsequent buffing or polishing. The nickel used is electro-refined wire or strip and is even purer than the product obtainable from the carbonyl process. The best metallic cobalt to use is that obtained by special reduction of the oxide, such as by the Kalmus process, which is completely free from carbon and practically all other solid impurities. For all smaller work it suffices to use nickel and cobalt inter-wound in the form of wire or strip, to present a uniform surface closely akin to a solid anode.

Nickel is analysed by the dimethylglyoxime method and cobalt by the nitroso- $\beta$-naphthol method. For initial experiments the cathode may be of platinum sheet, so that all features of the deposition at different current densities and concentrations of the two metals can be followed, before commencing operations. The deposits can be made very ductile, so as to bend or twist without any tendency to lift or peel, while what is known as 'double-plate' is rarely encountered.

Earlier work done by Fink and Lah proved the wide range of silver-white deposits which could be obtained from different cobalt nickel compositions, which in combined chloride-sulphate baths can contain 55-75 per cent of nickel with 45-25 per cent of cobalt. Afterwards, Young and Gould found that the mixed bath can provide almost any desired com. position of deposit at a current density of from 10 to $30 \mathrm{amp}$./sq. ft., with or without agitation. Researches by Brockman and Nowlen showed that the density can be increased to between 32 and $144 \mathrm{amp} . / \mathrm{sq}$. ft. with a different type of electrolyte. Advantage has been taken of a similar composition for the dual deposition in a bath consisting (in oz./gal.) of $26 \cdot 1$ nickel sulphate crystals, $4 \cdot 7$ cobalt sulphate crystals, 2 sodium chloride, and $3 \cdot 25$ boric acid, maintained 